\title{
Stanley Plotkin: the bright spark of cytomegalovirus vaccines
}

\author{
Edward S. Mocarski
}

Received: 24 December 2014 / Accepted: 7 February 2015 / Published online: 20 March 2015

(C) Springer-Verlag Berlin Heidelberg 2015

It is a tremendous pleasure and indeed honor for me to introduce Dr. Stanley Plotkin, a living legend in the world of vaccines, who will present a personal view of the current state of affairs in cytomegalovirus (CMV) vaccine development (Fig. 1). Dr. Plotkin, more than any other individual, has contributed to the progress in vaccine research and development since the idea of universal vaccination to prevent CMV congenital disease was proposed nearly 50 years ago. After completing his medical training just about the time CMV was first isolated and following a few years working for the Centers for Disease Control in the Epidemic Intelligence Service, from 1960 to 1991 , he directed a vaccine research group at the Wistar Institute and maintained clinical affiliations with the University of Pennsylvania and Children's Hospital of Philadelphia. Dr. Plotkin is most renowned and recognized for his pioneering work on viral vaccines. His research expanded the portfolio of children's vaccines currently available to combat widespread infectious diseases, including rubella, polio, rabies, rotavirus diarrhea and varicella (chicken pox). His success in the development of a live-attenuated rubella vaccine, currently in use worldwide, prompted a follow-up focus to address the need for a CMV vaccine, most likely due to the many common attributes between German measles-associated congenital disease and patterns of CMV disease, despite their marked differences in biology.

This article is part of the Special Issue on Cytomegalovirus.

Special acknowledgement to Eva Gonczol, Ph.D., Virology, National Center for Epidemiology, Budapest, Hungary.

E. S. Mocarski $(\square)$

Department of Microbiology and Immunology, Emory Vaccine

Center, Emory University School of Medicine, Atlanta, GA

30322, USA

e-mail: mocarski@emory.edu
Dr. Plotkin probably never envisaged a lifelong courtship with CMV vaccine initiatives when he began investigating CMV some 45 years ago. His initial focus was, of course, the live-attenuated Towne vaccine, which he escorted through clinical development that included: (1) the demonstration of safety and efficacy in solid organ transplant recipients [1], (2) the hallmark demonstration that the vaccine strain was unable to reactivate and so lacked the biological property of latency [2] and (3) a test of safety and efficacy against experimental challenge with the limited-passage Toledo strain [3]. He chose to recruit Catholic monks as vaccinees; thus, eliminating any risk for pregnant women or children after infectious challenge with the Toledo strain. These important milestones in the 1970s and 1980s engaged many talented associates and envisaged eventual success for this vaccine strategy. His research led to the first contemporary concepts of CMV vaccination, including the importance of cellular immunity to the conservation of protective antigens among circulating strains and the benefit of natural and experimental challenge [3-5]. These concepts challenged the conventional confidence in antiviral antibody as the sole mediator of immunity, a theme that continues to be debated today. Along the way, his report of a vaccine efficacy against CMV-associated opportunistic disease in solid organ transplant recipients [1] was an accomplishment as the first success of a vaccine for an opportunistic infectious disease. Ultimately, Towne vaccine was effective in kidney transplant patients, but proved less potent than natural infection in women of childbearing age when they were evaluated for resistance to natural mucosal acquisition of virus [6]. These studies portrayed an opportunity that has been pursued with other vaccine strategies, both live and nonlive, while Towne vaccine has been sidelined.

Whereas over the years he dedicated his research enterprise to establishing a CMV live-attenuated vaccine 


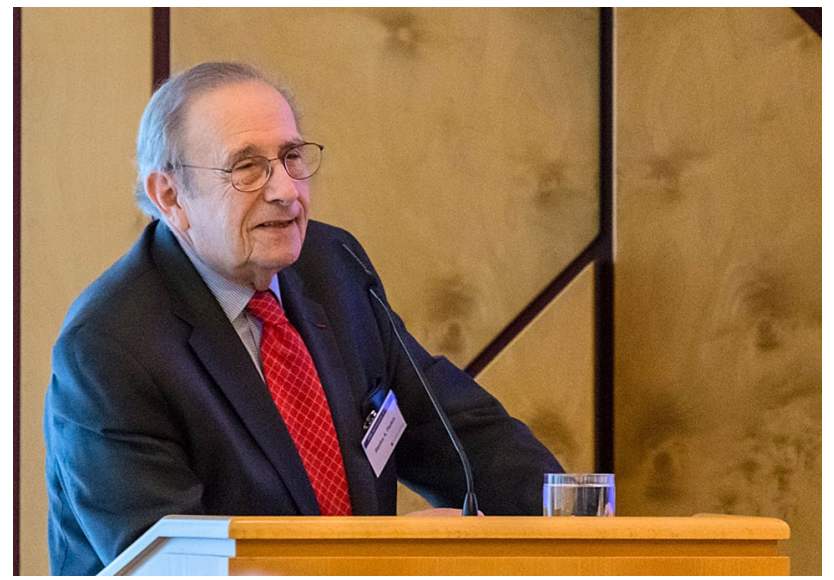

Fig. 1 Lecture given by Dr. Stanley Plotkin at the symposium "Margaret Gladys Smith 60th Anniversary of Cytomegalovirus Isolation," Waldthausen Castle, Germany, November 21, 2014 (photograph by courtesy of Dipl. Ing. Michael Reddehase)

platform, he is also acknowledged for numerous contributions to the basic understanding of CMV biology long before this became a defined field. Dr. Plotkin has received many accolades and honors that acknowledge his accomplishments, including election to the Institute of Medicine of the National Academy of Sciences (USA), the Sabin Gold Medal Award, the French Legion of Honor Medal and the Maxwell Finland Award for Scientific Achievement from the Infectious Disease Society. From 1991, after retiring from active academic research, Dr. Plotkin took on the roles of chief protagonist and statesman of CMV vaccines, first as Medical and Scientific Director at Pasteur Mérieux Connaught and later becoming consultant to Sanofi Pasteur. Today, he is consultant to the world. It is fair to say that no CMV vaccine candidate comes to light without the benefit of his publications and personal guidance. A biography accompanying the Maxwell Finland Award is a source record of Dr. Plotkin's career (http://www.nfid.org/awards/ finland).

Dr. Plotkin's research efforts with Dr. Toru Furukawa resulted in seminal contributions to the basic biology of $\mathrm{CMV}$, including the initial reports that characterized the remarkable ability of this herpesvirus to stimulate cellular metabolism, along with driving dramatic expansion of mitochondrial DNA, and the ability of viral structural components to meter cellular stimulation $[7,8]$. This effort included the ability to stimulate a coinfecting RNA virus [9]. At about the same time he was running complex vaccine trials, Dr. Plotkin published hallmark observations with Dr. Eva Gonczol that brought to light the dependence of CMV replication on the differentiation state of cells [10, 11] and stimulation of human immunodeficiency virus upon coinfection [12]. In addition to these key observations, Dr. Plotkin made his laboratory a CMV hub, helping investigators interested in taking up the study of CMV and providing viral strains that have helped define the characteristics of virulence and attenuation. Very importantly, after being nucleated through Dr. Plotkin's direct research, these basic questions have remained at the center of CMV biology in the decades since his seminal contributions appeared.

Throughout the years, preclinical evaluation of liveattenuated, non-live and vectored CMV vaccine candidates have been undertaken by Dr. Plotkin's research group. Pioneering virological and immunological properties as well as practical assay endpoints have been the consistent output from this research. Throughout his career, Dr. Plotkin retained fixed interest in the live-attenuated Towne vaccine candidate, he first brought onto the scene almost 40 years ago [13]. As the pioneer in the area of CMV vaccine development, Dr. Plotkin applied skills he had honed in the successful control of rubella virus to bear, including the use of secondary cultures of human fetal fibroblasts as a substrate for propagation of the vaccine. Dr. Plotkin supported decades-old efforts to "dial-up" Towne efficacy through the construction and evaluation of Towne-Toledo chimeras by Aviron (now MedImmune, a subsidiary of AstraZeneca) or the more recent introduction of the $\mathrm{gH} / \mathrm{gL}$ pentamer into a replication defective AD169 strain taken into clinical trials by Merck. He has also supported budding efforts to "dialdown" a clinical strain as possible vaccine vector platform that may well see the light of clinical trials. This long-term relationship with such a complex virus may be considered "Stanley's mistress" in one view. Dr. Plotkin certainly got a firsthand taste of the duplicitous nature of this relationship, reporting the first hint of immune modulation by CMV by characterizing the viral IgG Fc receptor [14]. He has also kept the light on for non-live vaccine strategies such as the MF59-adjuvanted gB subunit vaccine that gave moderate, but poorly durable success [15]. This vaccine was transferred from Chiron to Sanofi Pasteur in the early 1990s under Dr. Plotkin's executive guidance.

Dr. Plotkin will now impart his considerable understanding of the breadth of issues related to long-needed universal CMV vaccine for prevention of congenital disease. He still imagines this goal achievable within his lifetime, leading all in the field to wish him a very long life!

\section{References}

1. Plotkin SA, Smiley ML, Friedman HM, Starr SE, Fleisher GR, Wlodaver C, Dafoe DC, Friedman AD, Grossman RA, Barker CF (1984) Towne-vaccine-induced prevention of cytomegalovirus disease after renal transplants. Lancet 1(8376):528-530

2. Plotkin SA, Huang ES (1985) Cytomegalovirus vaccine virus (Towne strain) does not induce latency. $J$ Infect Dis 152(2):395-397 
3. Plotkin SA, Starr SE, Friedman HM, Gonczol E, Weibel RE (1989) Protective effects of Towne cytomegalovirus vaccine against low-passage cytomegalovirus administered as a challenge. J Infect Dis 159(5):860-865

4. Starr SE, Dalton B, Garrabrant T, Paucker K, Plotkin SA (1980) Lymphocyte blastogenesis and interferon production in adult human leukocyte cultures stimulated with cytomegalovirus antigens. Infect Immun 30(1):135-139

5. Quinnan GV Jr, Delery M, Rook AH, Frederick WR, Epstein JS, Manischewitz JF, Jackson L, Ramsey KM, Mittal K, Plotkin SA et al (1984) Comparative virulence and immunogenicity of the Towne strain and a nonattenuated strain of cytomegalovirus. Ann Intern Med 101(4):478-483

6. Adler SP, Starr SE, Plotkin SA, Hempfling SH, Buis J, Manning ML, Best AM (1995) Immunity induced by primary human cytomegalovirus infection protects against secondary infection among women of childbearing age. J Infect Dis 171(1):26-32

7. Furukawa T, Fioretti A, Plotkin S (1973) Growth characteristics of cytomegalovirus in human fibroblasts with demonstration of protein synthesis early in viral replication. J Virol 11(6):991-997

8. Tanaka S, Furukawa T, Plotkin SA (1975) Human cytomegalovirus stimulates host cell RNA synthesis. J Virol 15(2):297-304
9. Furukawa T, Jean JH, Plotkin SA (1978) Enhanced poliovirus replication in cytomegalovirus-infected human fibroblasts. Virology 85(2):622-625

10. Gonczol E, Andrews PW, Plotkin SA (1984) Cytomegalovirus replicates in differentiated but not in undifferentiated human embryonal carcinoma cells. Science 224(4645):159-161

11. Andrews PW, Gonczol E, Fenderson BA, Holmes EH, O’Malley G, Hakomori S, Plotkin S (1989) Human cytomegalovirus induces stage-specific embryonic antigen 1 in differentiating human teratocarcinoma cells and fibroblasts. J Exp Med 169(4):1347-1359

12. Hirka G, Prakash K, Kawashima H, Plotkin SA, Andrews PW, Gonczol E (1991) Differentiation of human embryonal carcinoma cells induces human immunodeficiency virus permissiveness which is stimulated by human cytomegalovirus coinfection. J Virol 65(5):2732-2735

13. Plotkin SA, Furukawa T, Zygraich N, Huygelen C (1975) Candidate cytomegalovirus strain for human vaccination. Infect Immun 12(3):521-527

14. Sakuma S, Furukawa T, Plotkin SA (1977) The characterization of IgG receptor induced by human cytomegalovirus. Proc Soc Exp Biol Med (New York, NY) 155(2):168-172

15. Pass RF (2009) Vaccine prevention of maternal cytomegalovirus infection. N Engl J Med 360(12):1191-1196 